DOI 10.15290/cnisk.2021.02.11.02

\author{
ALEKSANDRA EWELINA MIKINKA \\ https://orcid.org/0000-0002-6000-8157 \\ Uniwersytet Łódzki
}

\title{
Powrót chłopomanii. O fascynacji folklorem we współczesnej polskiej prozie fantastycznej
}

\begin{abstract}
Streszczenie
Powrót „mody na folklor” i nawrót fascynacji sztuką ludową dostrzegalne sa dziś w rozmaitych przestrzeniach oraz tekstach kultury. Wzorem państw zachodnich, które „odzyskują" współcześnie dawne wierzenia, obyczaje i obrzędy, Polska oraz inne kraje słowiańskie przeżywaja powtórnie „chłopomanię". Te trendy znalazły swoje odbicie także we współczesnej literaturze fantastycznej. W ciagu ostatnich dwudziestu lat powstało wiele powieści nawiąujących do życia i obrzędowości mieszkańców wsi (często $z$ okolic Podlasia). Ludowe wierzenia, żywe i kultywowane, stają się w nich punktem wyjścia do skonstruowania zaskakującej i pomysłowej fabuły. W artykule porównano „folkowe” powieści, które łączy postać głównej bohaterki - szeptuchy, wiedźmy, znachorki - będącej niejako symbolem tego, co wiejskie, „z ludu”, „z gminu”.

Słowa kluczowe: chłopomania, folklor, powieści folkowe, słowiańska fantasy, Baba Jaga, szeptucha
\end{abstract}




\title{
THE RETURN OF PEASANT-MANIA. THE FASCINATION WITH FOLKLORE IN MODERN POLISH FANTASY PROSE
}

\begin{abstract}
The return of 'folklore fashion' and the renewed fascination with folk art can be seen at present in various spaces and culture-based texts. Following in the footsteps of Western countries that are now 'reclaiming' old beliefs, customs, and rites, Poland and other Slavic countries are reliving their 'peasant mania'. These trends have also been reflected in contemporary fantasy literature; over the past twenty years, many novels have referred to the life and rituals of village dwellers (often from the Podlasie region). Folk-based beliefs, which are part of everyday life and culture, become the starting point for the construction of a surprising and ingenious storyline. This article compares the 'folk' novels that are linked through the type of main character - whisperers, witches, faith healers - who in some way symbolise the rural, the folk, the commoner-related.

Keywords: peasant-mania, folklore, folk novels, slavic fantasy, Baba Yaga, whisper
\end{abstract}

\section{Wprowadzenie}

Powrót „mody na folklor” i refascynacja sztuka ludowa dostrzegalne sa dzisiaj w rozmaitych przestrzeniach oraz tekstach kultury. Wzorem państw zachodnich, które „odzyskuja” współcześnie dawne wierzenia, obyczaje i obrzędy, Polska oraz inne kraje słowiańskie przeżywają powtórnie „chłopomanię”.

Inspiracje kultura i obrzędowością wsi zyskały dziś zupełnie nowe oblicze, czerpiąc garściami już nie tylko z estetyki ludowej, ale i sięgając dalej, do wierzeń dawnych Słowian, a raczej do naszego mglistego wyobrażenia o nich. Ruch rodzimowierczy ${ }^{1}$, przez ostat-

\footnotetext{
1 „Rodzimowierstwo słowiańskie, nazywane niekiedy słowianowierstwem, jest religia etniczna nawiązująca do przedchrześcijańskich wierzeń Słowian. W dyskursie naukowym jest ono zaliczane do nurtu neopogaństwa. Rodzimowierstwo jest znacznie zróżnicowane na gruncie lokalnym, zwłaszcza na osi wschód-zachód Słowiańszczyzny, czy inaczej na osi Ruś-Lechia. Ze względu na niedostatek źródeł historycznych oraz jednolitego dyskursu naukowego dotyczącego religii Słowian, rodzimowiercy stosuja niekiedy zabiegi rekonstrukcji czy wręcz konstrukcji kulturowej po to, by wypełnić białe plamy na mapie wierzeń słowiańskich...” Konrad Kośnik, „Tożsamość współczesnych rodzimowierców słowiańskich. Studium psychologiczne aktywności internetowej rodzimowierców w Polsce”, Przegląd Religioznawczy, nr 3 (257), 2015, 119-134.
} 
nie dziesięciolecia rosnący w siłę na terenie całej Słowiańszczyzny, stał się źródłem pomysłów dla twórców nowego nurtu obecnego na gruncie polskiej literatury - inspirowanego nie tylko folklorem, ale i wiara dawnych Słowian, powracajacca teraz w nowej odsłonie. Dziś odradza się także popkulturowa moda na wyżej wspomniany folklor, a raczej utwory (i wy-twory) nim inspirowane. Do ludowego dorobku kultura odwołuje się dziś na wielu poziomach: nie tylko w literaturze i filmie, ale też na gruncie muzyki, organizowanych imprez masowych, wspólnych aktywności społecznych, sportu, modnej odzieży i dodatków do stroju² ${ }^{2}$.

Warto zaznaczyć, że inspiracja słowiańszczyzną i inspiracja polskim folklorem stanowia bez wattpienia zjawiska osobne, jednakże ze względu na specyfikę kultury i obrzędowości ludowej oraz szczatkowa wiedzę na temat faktycznego przebiegu przedchrześcijańskich rytuałów często się one przenikają. Watki, motywy, postaci obecne w wiejskich legendach moga mieć bardzo stary rodowód, a prowincjonalny bestiariusz, choć już „schrystianizowany”, obfituje w potwory znane nam $z$ pogańskich wierzeń.

Synkretyczne przenikanie wpływów i wątków obecne jest także na gruncie literatury inspirowanej współczesną modą na „to, co ludowe”, „to, co z gminu”.

\section{Przykładowe realizacje ostatniego dwudziestolecia - polskie powieści fantastyczne czerpiące $\mathrm{z}$ folkloru}

Przykładem takiego przenikania i luźnego traktowania proweniencji opisywanych zwyczajów i obrzędów (jeszcze chrześcijańskie czy już pogańskie, a może na odwrót?), znamiennego dla dzieł kultury popularnej, sa rozmaite utwory współczesne wydane na przestrzeni ostatnich dwudziestu lat, którym przyjrzymy się w niniejszym artykule. Pierwszy z nich, autorstwa Anny Brzezińskiej, obejmuje dwa tomy opowiadań: Opowieści z Wilżyńskiej Doliny

\footnotetext{
2 Te nawiązania do folkloru na gruncie popkulturowym rozszerzaja, jak pisał Michał Waliński, znaczenie terminu: „W znaczeniu obiegowym, potocznym pojęcie folkloru staje się zazwyczaj synonimem nie tylko całej kultury ludowej, ale wszystkiego, co wiejskie i z wsia związane”. Michał Waliński, „Folklor i folklorystyka. Kilka uwag wstępnych”, w: idem, Teoria kultury. Folklor a kultura, (Katowice: Wydawnictwo Uniwersytetu Śląskiego, 1978), 40.

3 Por. Beata Walenciuk-Dejneka, „Święta znachorka - literackie realizacje sacrum w religijności ludowej na wybranych przykładach”, w: Zdzisław Kupisiński (red.), Chrześcijaństwo w religijności ludowej - 1050 lat po Chrzcie Polski, (Lublin: Wydawnictwo KUL, 2017), 200.
} 
(2002) oraz Wiedźma z Wilżyńskiej Doliny (2010). Drugi, nowszy, to cykl Katarzyny Bereniki Miszczuk pt. Kwiat paproci (2016-2019). U obu pisarek podstawą konceptu, na którym zbudowano fabułę książek, jest kreacja alternatywnego świata, w którym Polska nie przyjęła chrztu i pozostaje państwem pogańskim. W różny sposób dochodzi tam natomiast do „gry” $z$ motywami i wierzeniami ludowymi, na różny sposób buduje się ironię i swoisty dystans związany $z$ humorystycznym aspektem tekstów. Oba cykle łączy także postać wioskowej wiedźmy, Baby Jagi - u Brzezińskiej - Babuni Jagódki, u Miszczuk - Jagi, czyli Jarogniewy. Nieco inną znachorkę i ludowe obrzędy ukazuje natomiast Iwona Menzel w powieści Szeptucha (2014), korespondująca jednak z saga Miszczuk. Tam znachorka leczy już chrześcijańskimi modlitwami do Boga, Matki Boskiej i świętych, jednak jej metody nie różnią się tak bardzo od metod „słowiańskiej” uzdrowicielki, w podobny sposób poprowadzona jest też w ksiażkach droga głównych, młodych bohaterek od buntu i wyparcia do akceptacji swego losu jako tej, która zostaje wybrana, wytypowana (przez los, Boga, bogów) na spadkobierczynię ludowej mądrości. Jeszcze nieco inną szeptuchą jest $z$ kolei stara Słaboniowa, czarownica z książki Stara Słaboniowa i spiekładuchy Joanny Łańcuckiej (2013), mieszkanka maleńkiej Capówki, gdzie obok zajętych swoimi sprawami prostych mieszkańców pojawiaja się od czasu do czasu strzygi, demony i upiory, które tylko bohaterka potrafi przegnać.

We wszystkich ksiażkach wyraźnie dostrzec można synkretyzm $-z$ jednej strony pomiędzy tym, co chrześcijańskie i pogańskie w ludowych wierzeniach bohaterów (Słaboniowa modli się do ikony Matki Boskiej i Dzieciątka, a na cmentarzu w Zaduszki nawet $z$ nimi rozmawia, ale demony, $z$ którymi walczy, maja już typowo pogańska proweniencję; Oleszczukowa uważa, że jej dar pochodzi od Boga, ale jej wnuczka jest przekonana, że babka „zawdzięczała swój dar mocy, która była tu, zanim jeszcze stanęły pierwsze krzy$\dot{z}$ e, i nigdy nie odeszła stąd na dobre"4), a $z$ drugiej strony synkretyzm inspiracji samych autorów, których nawiązania do lokalnych mitologii, magii, rytuałów i wierzeń przechodza płynnie od fascynacji „tym, co wiejskie” (np. współczesnym Podlasiem, gdzie wszystko ma być bardziej „autentyczne” niż w miastach) do „tego, co dawne” (żyznej, zalesionej, na poły mitycznej krainy dawnych Słowian).

4 Iwona Menzel, Szeptucha, (Warszawa: Wydawnictwo MG, 2014), 7. 
Każda $z$ wiedźm przedstawionych w powieściach jest w pewnym sensie podobna do pozostałych (jak w baśni i legendzie, z których wywodzi się fantastyka), ale każda ma tė̇ wyjątkowe cechy charakteru. Większość z nich nosi przydomek Baba Jaga. U Brzezińskiej jest to Babunia Jagódka, nazywana przez miejscowych „stara, parszywa wiedźma”, u Miszczuk tytułowa szeptucha to Baba Jaga lub po prostu Jaga, Jarogniewa ${ }^{6}$. Sama postać Baby Jagi w ludowych wierzeniach jest dużo bardziej niejednoznaczna i skomplikowana niż w baśniach i legendach europejskich, w których często pojawia się już jako antagonistka, a nie potężne leśne bóstwo ${ }^{7}$. Współcześni autorzy dobrze oddaja ów ambiwalentny stosunek wiejskiej społeczności do Baby Jagi. Wiedźmy budzą lęk wśród mieszkańców, ale jednocześnie sa niezbędnymi i niezastąpionymi figurami wspólnoty, stojącymi niejako na straży porządku świata.

Jednym z najważniejszych i kluczowych elementów wiążących wszystkie współczesne opowieści inspirowane kultura i obrzędowością wsi jest to, że ich akcja dzieje się na dalekiej prowincji, oddalonej o wiele kilometrów od najbliższego miasta. W przypadku Brzezińskiej: „Z Wilżyńskiej Doliny wszędzie było daleko"8 - i choć autorka sytuuje akcję w wyimaginowanym świecie, czytelnik rozumie, że w rzeczywistości jest to satyryczne ukazanie Polski, choć o średniowiecznym sztafażu (zabieg często stosowany w literaturze gatunku fantasy ${ }^{9}$ ). Miszczuk z kolei umieszcza akcję swojej powieści w Bielinach, w alternatywnej Polsce, której władcy zdecydowali się nigdy nie przyjąć chrztu. Waniuszki oraz Capówka, wsie, w których akcję umiejscawiaja Menzel oraz Łańcucka, wymyślone zostały na potrzeby powieści, ale wyraźnie inspirowane były ruralistycznym krajobrazem Podlasia.

W przypadku Babuni Jagódki oraz Jarogniewy wiele razy w powieściach podkreśla się ich przedsiębiorczość czy wręcz materializm, chęć wykorzystywania swoich darów oraz swej wiedzy

\footnotetext{
5 Anna Brzezińska, Opowieści z Wilżyńskiej Doliny, (Kraków: Wydawnictwo Literackie, 2016), 7 .

$6 \quad$ Katarzyna Berenika Miszczuk, Szeptucha, (Warszawa: W.A.B., 2016), 47.

7 Zygmunt Krzak, Od matriarchatu do patriarchatu, (Warszawa: Wydawnictwo Trio, 2007), 371-373.

8 Anna Brzezińska, Opowieści z Wilżyńskiej Doliny, 5.

9 Edyta Rudolf, „Obecność słowiańskiego folkloru we współczesnej polskiej literaturze fantastycznej", w: Iwona Rzepnikowska (red.), Inspiracje ludowe w literaturach słowiańskich XI-XXI wieku, (Toruń: Wydawnictwo UMK, 2009), 201.
} 
w celach zarobkowych, jednak w miarę rozwoju wypadków ostatecznie owa postawa okazuje się jedynie maska, którą przywdziewaja, a pod nia kryja szlachetniejsze intencje. Inaczej jest ze stara Oleszczukowa, bohaterka Szeptuchy autorstwa Menzel: „Leczyła modlitwą i ziołami, potrafiła zamawiać choroby i odczyniać uroki" ${ }^{\prime 10}$. Kobieta nie czyni innym krzywdy, ponieważ uważa, że jej dar pochodzi od Boga i dlatego służy czynieniu dobra. Nie zmienia to jednak faktu, że lokalna społeczność, mimo że często zwraca się do niej o pomoc, jednocześnie boi się, iż szeptucha może w każdej chwili zmienić zdanie i wykorzystać swoja wiedzę do tego, by im zaszkodzić. Tak samo jest $\mathrm{w}$ przypadku każdej $z$ opisanych staruszek. O Słaboniowej: „Mówiło się we wsi, że to wiedźma, że potrafi urok rzucić ...”"11, u Oleszczukowej: „pacjenci szukali ... ostatniego ratunku, kiedy zawiódł już ksiądz i lekarz, ... jednak obawiali się jej tajemnej mocy"12. Na Babunię Jagódkę okoliczni mieszkańcy wyrzekaja ze strachem i nienawiścia, uważają, że jest „odpychająca, jak mało kto"13, planuja pewnego dnia spalić ja na stosie, ale nie przeszkadza im to jednocześnie chadzać do niej po medykamenty - leczy nawet miejscowego kapłana, który uważa, że każda wioska powinna mieć swoją wiedźmę ${ }^{14}$.

Niezależnie od proweniencji darów posiadanych przez bohaterki metody ich leczenia opisane sa w podobny sposób. Podstawę w każdym przypadku stanowią zioła. U Miszczuk w chatce szeptuchy: „Ładnie pachniało ziołami i suszonymi grzybami, które były rozwieszone na belkach pod sufitem"15, a sama Jarogniewa ma ogromną wiedzę o roślinach, która stara się przekazać swojej uczennicy, Gosławie, przygotowując je w tradycyjny sposób: „Baba Jaga ugniatała zioła w dużym kamiennym moździerzu" ${ }^{16}$. Jak sama twierdzi, wierzy, że maści, napary i wywary z ziół moga leczyć równie dobrze co farmaceutyki $z$ apteki. Podobnego zdania jest Oleszczukowa $z$ powieści Menzel oraz jej uczennica Olesia. Już od wczesnego dzieciństwa świetnie zna lecznicze właściwości ziół i kwiatów.

\footnotetext{
Iwona Menzel, Szeptucha, 7.

11 Joanna Łańcucka, Stara Słaboniowa i spiekładuchy, (Gdańsk: Oficynka, 2017), 48.

12 Iwona Menzel, Szeptucha, 8.

13 Anna Brzezińska, Opowieści z Wilżyńskiej Doliny, 42.

14 Ibidem, 8.

15 Katarzyna Berenika Miszczuk, Szeptucha, 45.

16 Ibidem, s. 75.
} 
Z kolei stara Słaboniowa przygotowuje różnego rodzaju napary dla okolicznych gospodarzy, aby pomóc im w walce $z$ nękajacymi ich demonami i stworami albo by naprostować ich życie uczuciowe. Do nękanej przez kauka ${ }^{17}$ Justynki mówi: „A zajdź do mnie, to ziółek ci dam"18, metodycznie i cierpliwie uczy także wiedzy o ziołach swoją sześcioletnią wnuczkę Olę. Scena wspólnego zbierania roślin obnaża niejednoznaczna moralnie naturę staruszki: ma rozległa wiedzę o leczniczych właściwościach ziół i kwiatów (jak każda szeptucha), ale potrafi też przygotować $z$ nich trucizny oraz słynna „maść czarownic” umożliwiająca latanie (jak każda czarownica). Oprócz wykorzystywania ziół w celu leczenia lub dręczenia innych zdarza się także, że szeptuchy przygotowuja ziołowe napary dla siebie, aby wzmocnić swoje magiczne umiejętności - w podobny sposób jak robił to Geralt $z$ Rivii w serii Andrzeja Sapkowskiego o Wiedźminie. Tym, co łączy wszystkie bohaterki, jest silne przekonanie, że ich specyfiki i medykamenty moga pomóc równie skutecznie co farmaceutyki. Jarogniewa zabiera swoja uczennicę ze szpitala, tłumacząc, że w domu rana na brzuchu, smarowana maścia jej roboty, zagoi się szybciej ${ }^{19}$. Słaboniowa $z$ kolei mówi córce: „O, do żadnego śpitala wy mnie nie dacie! ... W śpitalu ludzie umirajo. Ja swoję maść $z$ borsuczego sadła mam i mnie starczy"20.

Szeptuchy przedstawione $\mathrm{w}$ powieściach łączy więcej elementów niż tylko leczenie ziołami. Ponieważ wszystkie wykreowane zostały na "stare, wiejskie baby”, toteż każda musi wyglądać, zachowywać się i mieszkać adekwatnie do swojej roli/postaci. Często podkreśla się charakterystyczny element ich stroju, jakim jest kwiecista chustka na głowie. Ta chustka staje się w powieściach folkowych symbolem tego, co wiejskie, przaśne, rustykalne. Ponadto każda $z$ bohaterek ma kota, zgodnie $z$ długa europejską tradycją czarowniczych chowańców, każda mieszka także w chatce na peryferiach wsi, tam, gdzie kończy się cywilizacja, a władztwo zaczyna przejmować natura. Niekiedy jednak te reprezentatywne dla szeptuchy elementy scenerii potraktowane zostaja ironicznie, przetransformowane przez filtr współczesności, jak w sadze Kwiat

\footnotetext{
17 Kauk - zły demon $z$ wierzeń wschodniosłowiańskich, przynoszący pecha mieszkańcom domostwa, w którym postanowi zamieszkać. Andrzej Kempiński, Encyklopedia mitologii ludów indoeuropejskich, (Warszawa: Wydawnictwo Iskry, 2001), 480.

18 Joanna Łańcucka, Stara Słaboniowa i spiekładuchy, 57.

19 Katarzyna Berenika Miszczuk, Przesilenie, (Warszawa: W.A.B., 2018), 21.

20 Joanna Łańcucka, Stara Staboniowa i spiekładuchy, s. 147.
} 
paproci, gdzie Jarogniewa posługuje się gwara, zakłada chustę na głowę, garbi się i wkłada w usta złotą licówkę jedynie na pokaz, a przed Gosława ukazuje swoje prawdziwe oblicze - eleganckiej, zadbanej, modnej starszej kobiety o nienagannej posturze, tłumaczac: „To dla klientów. Nie wystarczy być dobrą szeptucha. W tych stronach trzeba jeszcze odpowiednio wyglądać" ${ }^{21}$. Świetnie i nie bez ironii podsumowuje to istotę fascynacji szeptuchami, opartej m.in. na naszym szczególnym wyobrażeniu o tym, jak powinny się prezentować (i jednoczesnej negacji ich umiejętności, jeśli noszą się jako zbyt „normalne”).

Figura wiedźmy, Baby Jagi, czarownicy, nabiera szczególnych cech i szczególnego znaczenia dopiero na tle wiejskiej społeczności, wśród której osadzona jest akcja. Podobnie jak u Reymonta faktycznym bohaterem opisywanych przygód jest gromada. Poprzez indywidualne perypetie wybranych przedstawicieli zbiorowości ukazuje się wycinek życia grupy zamieszkującej wieś. Najczęściej asumpt do przedstawienia losów bohatera bądź bohaterki stanowi fakt, że zwracają się oni po poradę do wiedźmy. Każda $z$ powieści ma natomiast inny wydźwięk w aspekcie oceny problemów, jakie niesie ze soba gminne życie. Brzezińska i Łańcucka nie uciekają od niełatwych tematów, a poprzez historie takie jak tragiczne losy wiejskiej prostytutki Gronostaj lub pogrom szczurołaków spowodowany nienawiścią na tle rasowym wyposażaja swoje powieści $\mathrm{w}$ watki trudne, poruszaja istotna i uniwersalna problematykę, nie stroniąc jednak przy tym od motywów ludycznych: sama Babunia Jagódka, jej pociag do alkoholu, ordynarne zachowanie, wulgarne słownictwo, często stanowią o istocie humoru obecnego w Opowieściach $z$ Wilżyńskiej Doliny.

Gromada zostaje ukazana na tle przemian społecznych, ekonomicznych i ustrojowych, jakich mieszkańcy polskich wsi doświadczyli w przeciagu ostatnich lat. W Szeptusze Menzel i Starej Słaboniowej Łańcuckiej społeczności Waniuszek i Capówki, żyjące na styku kilku kultur, reprezentuja „magiczna” krainę Podlasia - zachodnia obrzędowość liturgiczna miesza się tutaj z prawosławiem, a oba wyznania w swych ludowych odmianach swobodnie łączą i splataja ze sobą wierzenia, zwyczaje i rytuały o proweniencji chrześcijańskiej i pogańskiej. Mieszkańcy na każdym kroku starają się podkreślać i pielęgnować swoją religijność. Jednocześnie

${ }_{21}$ Katarzyna Berenika Miszczuk, Szeptucha, 46. 
kult ziemi realizuje się tu na sposób, który człowiek wiązał ze sfera sacrum od czasów najbardziej pierwotnych: „cudownych figurek, obrazów i źródełek u nas nie brakowało"22. Okoliczni mieszkańcy oddają cześć nie tylko wizerunkom świętych oraz Matki Boskiej, ale wierza także w magiczne moce obiektów przyrodniczych.

Silna wiara mieszkańców wsi koresponduje $z$ ich przekonaniem o magicznych mocach szeptuch, do których chadzaja. Jednocześnie to właśnie ta wiara stanowi istotę fascynacji terenami wiejskimi na gruncie literatury fantastycznej. Koncept, na którym opiera się fabuła wszystkich powieści, polega na nadaniu owym wierzeniom, przesądom, często zabobonom, znamion prawdziwości. Dlatego w Starej Słaboniowej, kiedy w wyjątkowo upalne lato kolejna osoba umiera $z$ powodu udaru słonecznego, staruszka od razu wie, że stoi za tym południca $^{23}$, której wieśniacy boją się od pokoleñ ${ }^{24}$, a gdy maleńka córeczka Anetki zanosi się płaczem, gromada $z$ szeptuchą na czele wie, że kolkę wywołuje kikimora ${ }^{25}$. Fantastyczne potwory stanowią symboliczna materializację ludzkich pragnień i grzechów, które mieszkańcy wsi starają się ukryć. Zamordowana za stodoła młoda dziewczyna powraca jako demon, którego zadaniem jest nie tylko zemsta, ale i ukazanie prawdy. W tym sensie, paradoksalnie, siły nieczyste stoja na straży moralnego porzadku świata. Ich reprezentantką poniekąd jest sama czarownica, postać niejednoznaczna moralnie (a nawet ontologicznie) - ta, która może zarówno pomóc, jak i zaszkodzić, ta, która wskazuje i karze winowajców, morderców, złodziei, albo przeciwnie, ratuje tych, którzy stali się wyrzutkami, znienawidzonymi przez gromadę (prostytutka Gronostaj i zbój Waligóra uratowani przez Babunię Jagódkę; złodziej Dziejek, którego broni Słaboniowa).

Ważnym aspektem wszystkich powieści jest fakt, że mieszkańcy zbiorowości, oraz same znachorki, mówia gwara. Stylizacja językowa może być niezwykle rozbudowana - jak w Starej Słaboniowej, gdzie narracja wyraźnie stara się imitować czy może nawia-

\footnotetext{
22 Iwona Menzel, Szeptucha, 12.

23 „POŁUDNICA była wyjątkowo niebezpiecznym polnym demonem znanym naszym słowiańskim przodkom. Powstawała $z$ kobiety, która zmarła tuż przed własnym ślubem lub chwile po nim. ... Człowiekowi napotkanemu przy pracy łamała kończyny, dusiła go, zsyłała paraliż i postrzał, a czasem widowiskowo urywała nieszczęśnikowi głowę. Zostawione bez opieki dzieci południca chowała do przepastnego wora i wynosiła do lasu, zabijała je od razu lub zakopywała żywcem pod miedza”. Paweł Zych, Witold Vargas, Bestiariusz słowiański: rzecz o skrzatach, wodnikach i rusałkach, (Olszanica: BOSZ, 2017), 148.

24 Joanna Łańcucka, Stara Słaboniowa i spiekładuchy, 131.

25 Ibidem, 101.
} 
zywać do języka Chłopów Reymonta - albo stanowić żartobliwy dodatek, jak w przypadku postaci Jarogniewy (Kwiat paproci), która podczas rozmów $z$ pacjentami pochodzacymi $z$ Bielin posługuje się gwara świętokrzyską, jednak $z$ warszawianką Gosławą rozmawia językiem standardowym.

Społeczność wiejska w Szeptusze autorstwa Menzel ukazana została na tle przemian ustrojowych mających miejsce w Polsce lat 90 . Wieś zmienia się, w miarę jak dorasta główna bohaterka, urodzona u schyłku epoki PRL. Analogiczny proces zachodzi w zamieszkiwanej przez Słaboniową Capówce. Do zmian na prowincji obie autorki podchodza inaczej. U Menzel silnie podkreśla się transformację ustrojowa, która doprowadziła poniekąd do degeneracji autentyzmu wsi, na zawsze zmieniła mentalność jej mieszkańców, pozbawiła ich możliwości izolacji, dzięki której dotychczas na Podlasiu przetrwały stare obrzędy i wierzenia. Wysyp turystów z Warszawy odbiera część podlaskiej „magii”, komercjalizuje ja, spłyca. Pod tą wierzchnią warstwa pozostaje jednak rdzeń, którego turyści nie sa w stanie wydrzeć, dotrzeć do niego - to, co stanowi o istocie mentalności mieszkańców wsi położonych na ścianie wschodniej. To, co jedni nazywaja „zacofaniem”, inni „naturalnościa”, „,autentycznościa”. Każda $z$ powieści stawia sobie za cel dotarcie do tej nieuchwytnej kwintesencji „wiejskości” i zamknięcie jej na kartach książki, uzyskując niepowtarzalny folkowy klimat. Menzel skłania się ku upatrywaniu istoty owego klimatu w religijności prostych ludzi, która przekłada się z kolei na całą filozofię ich życia. Ta cykliczność, ład i rytm, wyznaczany przez święta kościelne, po raz kolejny odsyła nas do Chłopów jako istotnego hipotekstu współczesnych powieści folkowych.

Ważnym aspektem każdej $z$ analizowanych historii jest relacja szeptuchy $z$ uczennica. Stara Oleszczukowa naucza Olesię, wnuczkę. Relacja, która staje się ich udziałem, widoczna jest także w warstwie leksykalnej - imię spadkobierczyni odpowiada nazwisku babki (Olesia - Oleszczukowa), jest jednak zdrobniałe, adekwatne do młodego wieku dziewczynki. Wskazuje to na „odradzający" się charakter wiedzy związanej z kobietami, odpowiadajacy prastaremu mitowi o Potrójnej Bogini, która wiecznie się odradza (Dziewicy, Matce, Staruszce) ${ }^{26}$. Olesia nie przyjmuje jednak swoje-

\footnotetext{
26 Krystyna Kossakowska-Jarosz, „Stara baba w ludowym obrzędzie - reorientacja jej recepcji na Górnym Śląsku”, w: Adrian Gleń, Irena Jokiel, Marek Szladowski (red.), Egzystencjalne doświadczenie starości w literaturze, (Opole: WUO, 2008), 129.
} 
go losu z wdzięcznością. Marzy o pracy lekarki w wielkim mieście, o opuszczeniu Waniuszek. Nagła śmierć babci sprawia jednak, że mieszkańcy pozostaja sami, bez wioskowej szeptuchy. Dlatego też dziewczyna, pomimo młodego wieku, akceptuje swój los, konstatując jednak, iż „skazuje on na samotność" ${ }^{27}$. Co istotne, nie wspomina się w tej historii o mężczyznach $z$ rodziny bohaterki. Wychowuje ja babcia, nie wiemy jednak nic o dziadku ani o ojcu dziewczyny. Jej świat jest światem matriarchatu, dlatego szeptuchy nie moga związać się na stałe $z$ żadnym mężczyzną. Pod koniec powieści okazuje się, że bohaterka jest w ciąży - urodzi dziewczynkę. Nie informuje o tym jednak ojca dziecka, reżysera $z$ Warszawy, ponieważ postanawia samotnie wychowywać potomkinię i „nauczyć ją wszystkiego, co sama umie"28. Koło magicznej wiedzy zatacza pełen obrót.

W powieściach silnie podkreślona jest opozycja wieś - miasto. To, co na prowincji ma rację bytu, jest realne, prawdziwe, rzeczywiste - w miastach staje się jedynie zabobonem, dalekim echem, fałszerstwem. Menzel surowo ocenia mieszkańców stolicy, którzy przybywają tłumnie do podlaskich agroturystyk, marząc o zobaczeniu „autentycznej” wsi. Bogaci i zepsuci wielbiciele swojskiego klimatu Podlasia stanowia u Menzel ironiczne odbicie grupy odbiorców całej współczesnej „mody na folklor”. Z jednej strony w agroturystykach pragna zaznać autentycznego klimatu Podlasia, $z$ drugiej pytaja, czy odbywać się w nich będą zajęcia jogi. Moda, nawet ta na "folklor”, staje się kosmopolityczna, cechuje ja synkretyzm i pomieszanie porządków. Społeczność wiejska w obliczu przemian ustrojowych oraz kształtującej się na polskiej prowincji branży turystycznej, wykorzystujacej zafascynowanie wsia, dzieli się na dwie grupy: jedni zaczynaja zarabiać na przyjezdnych urlopowiczach, inni izolują się od zewnętrznego świata jeszcze bardziej, obawiając się go i nie rozumiejac.

\section{Zakończenie}

Folklor w dzisiejszych powieściach fantastycznych został potraktowany $z$ różnym stopniem powagi. Niektóre $z$ przedstawionych w niniejszym artykule pozycji traktuja „wiejski” klimat jako

27 Iwona Menzel, Szeptucha, 117.

28 Ibidem, s. 299. 
atrakcyjny dodatek fabularny, który jednak pozostaje jedynie elementem sztafażu, dziś być może równie egzotycznym, co umiejscowienie akcji $\mathrm{w}$ dalekim kraju. Twórcom literatury fantasy $z$ rzadka chodzi o zaprezentowanie czytelnikom rzeczywistego studium z życia i obyczajowości wsi, a raczej o przetworzenie materiału źródłowego w jakimś nadanym przez siebie celu. Na przykład, jak zauważa Małgorzata Tkacz, „postaci z ludowego bestiarium moga pełnić funkcję terapeutyczna" 29 - tak jest zarówno w przypadku powieści Brzezińskiej, jak i Łańcuckiej. Czy demony rzeczywiście istnieja, czy sa jedynie przyobleczonymi w pół ludzkie kształty wyrzutami sumienia mieszkańców Capówki, widzianymi czy to noca, czy w stanie nietrzeźwości, czy w gorączce - o tym wie tylko stara Słaboniowa. Nieprzypadkowo jednak każda $z$ kilku zamkniętych i samodzielnych historii zaprezentowanych w powieści ma swój początek w grzechu czy zbrodni, jaka stała się udziałem miejscowych.

Nieco inaczej do tematu prowincji podchodzą autorzy książek przynależących do nurtu realizmu magicznego, jak analizowana tu Menzel czy chociażby Jakub Małecki (Dygot, 2015). W Szeptusze nie znajdziemy potworów i demonów, a raczej apoteozę polskiej wsi „nieskalanej” branżą turystyczna. Menzel zdaje się wierzyć, że prowincjonalne miejscowości i miasteczka pozostały jedynymi strażnicami tożsamości narodowej, przechowywanej w pamięci prostego ludu, które nie zdołały się jeszcze skosmopolityzować, choć nieuchronnie do tego zmierzają. W pewnym sensie tę tożsamość reprezentować ma postać szeptuchy, strażniczki wiedzy (o ziołach, obrzędach, specyfikach), wykonawczyni rytuałów, celebrantki wiejskich obyczajów. Szeptucha w zasadzie w każdej z „folkowych” powieści - urasta do rangi symbolu, najważniejszego symbolu tego, co wiejskie. Jedynie odpowiedź na pytanie, co w takim razie naprawdę oznacza „wiejskość”, za każdym razem jest inna. Jeden element łączy jednak nie tylko utwory literackie, ale chyba wszystkie teksty kultury inspirowane „rustykalnym” klimatem - wiejskie jest to, co autentyczne/naturalne (choć niekiedy zacofane). Ta naturalność, nawet jeśli tylko pozorna, przyciąnęła na wieś i wywołała pierwsza falę ludomanii ponad sto lat temu. Teraz, zdaje się, moda na folklor wykorzystuje dokładnie te same mechanizmy i tęsknoty, które nieodmiennie w nas tkwią.

\footnotetext{
29 Małgorzata Tkacz, „Demonologia ludowa w fantasy Anny Brzezińskiej”, w: Adrian Mianecki, Agnieszka Osińska, Luiza Podziewska (red.), Folklor w badaniach współczesnych, (Toruń: Wydawnictwo UMK, 2005), 179-189.
} 


\section{Bibliografia}

\section{Źródła}

Brzezińska, Anna. Opowieści z Wilżyńskiej Doliny, (Kraków: Wydawnictwo Literackie, 2016).

Brzezińska, Anna. Wiedźma z Wilżyńskiej Doliny, (Kraków: Wydawnictwo Literackie, 2016).

Łańcucka, Joanna. Stara Słaboniowa i spiekładuchy, (Gdańsk: Oficynka, 2017).

Menzel, Iwona. Szeptucha, (Warszawa: Wydawnictwo MG, 2014).

Miszczuk, Katarzyna Berenika. Przesilenie, (Warszawa: W.A.B., 2018).

Miszczuk, Katarzyna Berenika. Szeptucha, (Warszawa: W.A.B., 2016). Miszczuk, Katarzyna Berenika. Żerca, (Warszawa: W.A.B., 2017).

Sapkowski, Andrzej. Ostatnie życzenie, (Warszawa: Supernowa, 2004).

Wyspiański, Stanisław. Wesele, (Kraków: Gebethner i Spółka, 1901).

\section{Opracowania}

Kempiński, Andrzej. Encyklopedia mitologii ludów indoeuropejskich, (Warszawa: Wydawnictwo Iskry, 2001).

Kośnik, Konrad. „Tożsamość współczesnych rodzimowierców słowiańskich. Studium psychologiczne aktywności internetowej rodzimowierców w Polsce”, Przegląd Religioznawczy, 3 (257), 2015, 119-134.

Kossakowska-Jarosz, Krystyna. „Stara baba w ludowym obrzędzie - reorientacja jej recepcji na Górnym Śląsku", w: Adrian Gleń, Irena Jokiel, Marek Szladowski (red.), Egzystencjalne doświadczenie starości w literaturze, (Opole: WUO, 2008).

Majchrowski, Jacek. „Wstęp”, w: Agnieszka Gajda, Jacek Majchrowski (red.), Neopogaństwo w Polsce, Państwo i Społeczeństwo, R. VIII, nr 4, 2008, 3-4.

Mianecki, Adrian. Osińska, Agnieszka. Podziewska, Luiza (red.), Folklor $w$ badaniach współczesnych, (Toruń, Wydawnictwo UMK, 2005).

Osowski, Błażej. „Drugie życie gwary-dialektyzacja w wybranych powieściach Katarzyny Bereniki Miszczuk", Socjolingwistyka, t. 33, 2019, 269-282. 
Pamięta-Borkowska, Joanna. „Polskie i rosyjskie myślenie mityczne na podstawie słowiańskiej literatury fantasy”, Acta Polono-Ruthenica, nr 16, 2011, 149-159.

Propp, Vladimir. „Morfologia bajki”, Stanisław Balbus (tłum.), Pamiętnik Literacki, t. 59, nr 4, 1968, 203-242.

Randolph, Pascal Beverly. Magia seksualna, Dariusz Misiuna (tłum.), (Warszawa: Wydawnictwo Okultura, 2010).

Rotter, Lucyna. „Rośliny - symbole, inspiracje czy pokarm: znaczenie roślin w kulturze ludowej”, w: Peter Tirpak, Peter Borza (red.), Znak, symbol a ritual $v$ tradiciach a prejavoch l'udovej zboznosti, (Prešov: Prešovská univerzita v Prešove, 2013), 121-140.

Rudolf, Edyta. „Obecność słowiańskiego folkloru we współczesnej polskiej literaturze fantastycznej", w: Iwona Rzepnikowska (red.), Inspiracje ludowe $w$ literaturach słowiańskich XI-XXI wieku, (Toruń: Wydawnictwo UMK, 2009), 199-214.

Sitniewska, Roksana. Wilczyńska, Elwira. Wróblewska, Violetta (red.), Folklor. Tradycja $i$ współczesność, (Torun: Wydawnictwo UMK, 2016).

Sulima, Roch. Folklor i literatura. Szkice o kulturze i literaturze wspótczesnej, (Warszawa: Ludowa Spółdzielnia Wydawnicza, 1985).

Walenciuk-Dejneka, Beata. „Święta znachorka - literackie realizacje sacrum w religijności ludowej na wybranych przykładach", w: Zdzisław Kupisiński (red.), Chrześcijaństwo $w$ religijności ludowej - 1050 lat po Chrzcie Polski, (Lublin: Wydawnictwo KUL, 2017).

Waliński, Michał. „Folklor i folklorystyka. Kilka uwag wstępnych”, w: idem (oprac.), Teoria kultury. Folklor a kultura, (Katowice: Wydawnictwo Uniwersytetu Ślasskiego, 1978), 7-40.

Wróblewska, Violetta. „Folklor w kręgu popkultury”, w: Janina Hajduk-Nijakowska, Teresa Smolińska (red.), Nowe konteksty badań folklorystycznych, (Wrocław: PTL, 2011), 131-146.

Wrzesińska, Anna. Słowiańska gimnastyka dla kobiet, (Gdańsk: Wydawnictwo Rosjanka, 2019).

Zych, Paweł. Vargas, Witold. Bestiariusz słowiański: rzecz o skrzatach, wodnikach i rusakkach, (Olszanica: BOSZ, 2017). 